\title{
下流進行する氷上のステップ地形 DOWNSTREAM MIGRATING STEPS ON ICE
}

\author{
内藤健介 ${ }^{1} \cdot$ 泉 $^{\text {典洋 }^{2} \cdot \text { 横川美和 }}{ }^{3} \cdot$ 山田朋人 ${ }^{2}$ \\ Kensuke NAITO, Norihiro IZUMI, Miwa YOKOKAWA and Tomohito YAMADA \\ 1 学生会員 北海道大学 大学院工学院 (广 060-8628 北海道札幌市北区北 13 条西 8 丁目) \\ 2 正会員 北海道大学 大学院工学研究院 (T 060-8628 北海道札幌市北区北 13 条西 8 丁目) \\ 3 正会員 大阪工業大学 情報科学部 (广 573-0171 大阪府枚方市北山 1-79-1)
}

\begin{abstract}
In recent years, cyclic steps are discovered in a variety of environments, such as deep ocean floors and ice floors on planets other than the earth. Water can exist only in the form of ice in the extraterrestrial environments, where temperature is commonly by far lower than that on the earth. Therefore, cyclic steps in the extraterrestrial environments are expected to be often found on ice. In order to obtain basic knowledge on the formation of ice steps, we have performed a series of experiments in a cold room of Institute of Low Temparetre Science, Hokkaido university, and reproduced ice steps migrating in the downstream direction. In this paper, we formulated the formation process of ice steps, and provide a reasonable explanation of the downstream migrating ice steps based on the experimental results.
\end{abstract}

Key Words: cyclic steps, ice bed, density flow, heat transfer

1.はじめに

サイクリックステップ1) は, 急勾配の河床や海底に 自由表面や密度界面を有する水の流れや乱泥流によっ て形成される周期的なステッフ状の地形である. 一つの ステップは上下流端に跳水を伴い, 上流端の跳水下流 では常流，下流端の跳水上流では射流で流れるという 特徵を有する . 流れと底面に何らかの擾乱が生じると 流速の大きな部分と小さな部分が生まれる. 兴の結果， 底面の侵食速度に場所的な差が生じ, 光れが発達する ことで連続したステップ状の地形が形成されていく2).

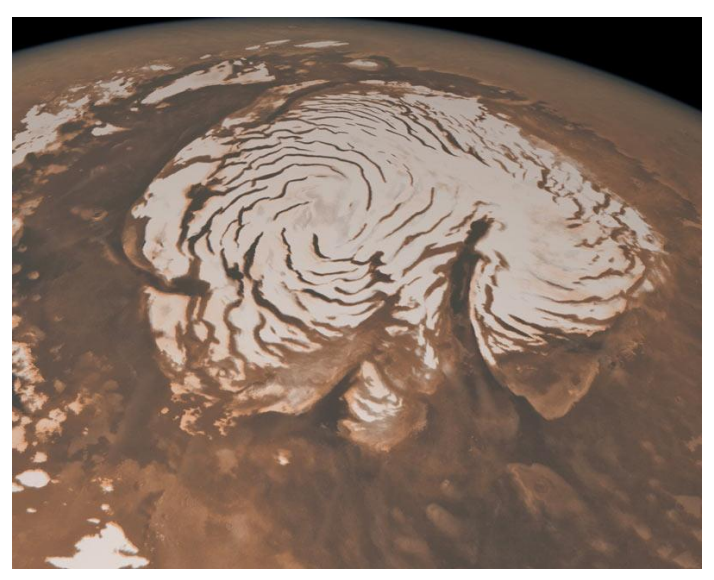

図-1 火星の北極冠に見られる spiral troughs. trough は北極 永床上で冷やされながらコリオリの力で螺旋状に滑降 するカタバ風と直交しており, カタバ風によって形成さ れるサイクリックステップである可能性がある . (NASA http://www.nasa.gov/)
これまでステップ地形としては, 細砂で覆われた河床 や海底で見られる transportational なものと粘性土や岩 盤など侵食が卓越する場で形成される purely erosional なものが知られてきたが, 近年では氷河や火星の北極 冠上など水の上にもステップ地形と酷似した地形が発 見されている゙)(図-1) . 火星の高緯度地域に見られる層 状堆積物は火星の気候変動など過去の歴史を読み解く 上で重要な情報を有する゙) ことから, 科学的に多くの注 目を集めている.今後, 宇宙開発が進むにつれて宇宙 環境下での各種構造物の建設や居住環境の整備が必要 となるが, 弚のための基礎的知見としても惑星表層の 物理環境に関する情報は工学的にも重要である．

本研究では, 流体によって水の上に形成される地形 について基礎的な知見を得るため，著者らがこれまで に行った氷上におけるステップ形成実験について，光 の概略を述へ，実験結果を基にステップ地形形成過程 の定式化を行うと同時に実験で観察された下流方向へ 伝播するステップに関する理論的説明を行う.

\section{2. 水床上におけるステップ形成のアナログ実験}

火星北極冠のステップ地形には,レーダーによる内部 構造の調査から , ステップ地形が上流へ進行したこと

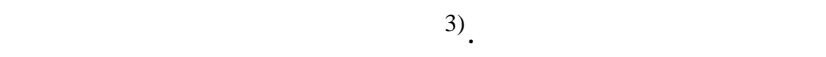
れる密度流中に含まれる水蒸気が土砂の役割を果たし， 昇華と沈殿を繰り返すことにより水上にステップ地形 が形成されると推測される.空気の密度流により水上 に形成されるステップを実験室で再現することは極め 
表-1 実験条件一覧

\begin{tabular}{|c|c|c|c|c|}
\hline CASE & Fr 数 & 水深 $(\mathrm{cm})$ & 流量 $\left(\mathrm{cm}^{3} / \mathrm{s}\right)$ & 勾配 $\left(^{\circ}\right)$ \\
\hline \hline $\mathrm{A}$ & 1.7 & 0.86 & 44.6 & 20 \\
\hline $\mathrm{B}$ & 1.01 & 0.75 & 34.6 & 30 \\
\hline
\end{tabular}

て困難であるため，本実験では火星の密度流と流体中 の水蒸気を，光れ光れ疎水性と不凍性を持つシリコン オイルと水でモデル化し，ポンプを用いてシリコンオ イルと水の混合液を底面を水で覆った水路内に循環さ せることでステップの形成を試みた .

水路はアクリル製で, 長さが $1.4 \mathrm{~m}$, 幅は実験を二次 元的に再現するために $2 \mathrm{~cm}$ としてある. また水路の両 端には高さ $8 \mathrm{~cm}$ の堰か設けてあり，堰の間に湛水して 水路全体を冷却することで水床を作製した . 温度設定 は低温室内をおよ光 $-7.0^{\circ} \mathrm{C}$ とし, シリコンオイルと水 の混合液の温度は混合液中の水の融解, 凝固どちらも 起こり得るおよ光 $-0.5{ }^{\circ} \mathrm{C}$ とした .この温度設定は火星 の場合を必ずしも模擬したものとなっていない．これ は実験装置の限界で火星の温度設定を模擬できなかっ たことと，当初，温度の影響より流速分布の影響を重 要と考えたことによる. 初期擾乱として水路上流端よ り $30 \sim 50 \mathrm{~cm}$ の地点に 1〜2 $\mathrm{cm}$ の切り欠けを設けた .

この条件での実験の結果では凝固による堆積が卓越 する状況となり，水床の高さが全体的に若干上昇しな がらステップ地形が発達する樣子が観察された .さら に一部のケースではステップが下流へ進行する樣子が 観察された .これまで知られていたサイクリックステッ プが上流へ進行するのに対して，この実験の条件下で は下流へ進行するステップが存在することが実験的に 示された

実験により形成された下流に進行するステップ地形 の一例及び実験条件を表-1 及び図-2に示す .

\section{3. 理論解析}

(1) 下流へ伝播するステップ

これまて知られているサイクリックステップは , purely erosional なものも transportational なものも全て上流へ 伝播する特性を持つことが知られてきたが，水上に形 成されたステップには下流へ進行するものが存在する ことが実験によって示された .この節では理論解析を 用いてこの現象を説明する．

底面が水でできた水路上をある流体が流れている状 況を考える . 流れている流体は水を含む踈水性の液体 であり，弚の融点は水より十分低いとする . 水の厚さの 初期值は苂であり, 光の下面で昷度が $\widetilde{T}_{b}$ に維持されて いるとする .一方 , 流れている流体の層厚は $\tilde{H}$ であり 液面の温度は $\tilde{T}_{a}$ に維持されているとする.$\tilde{T}_{a}$ 及び $\tilde{T}_{b}$ の両方，あるいはどちらか一方が十分低温であり水の
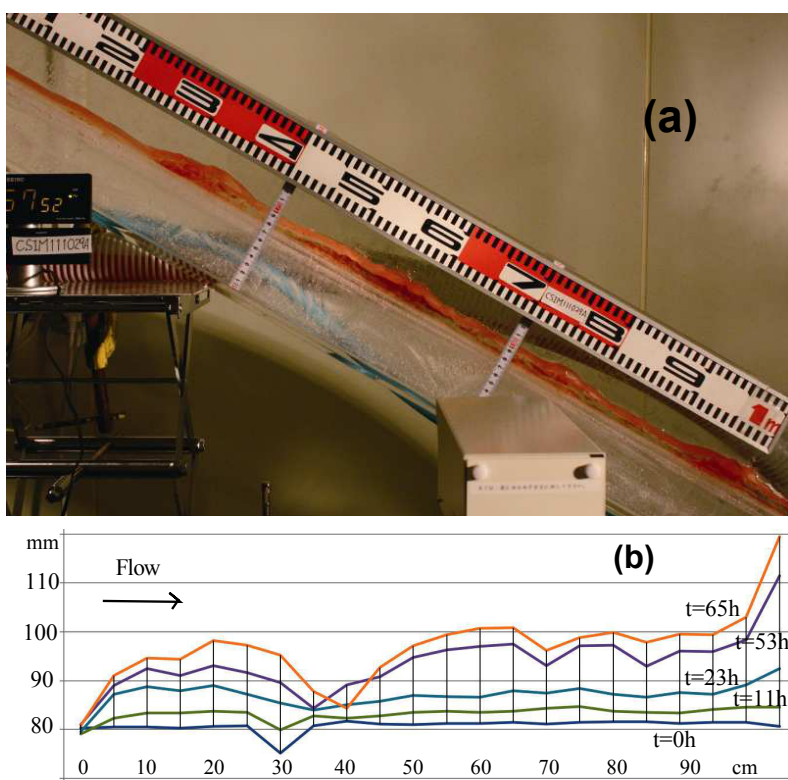

図-2 (a) 実験結果 . 10〜15cm の波長のステップ状地形が 3〜 4 個形成されていることがわかる. (b) 水の厚さの時間変 化 . $30 \mathrm{~cm}$ のポイントの切り欠けが流下方向へ移動して いるのがわかる .

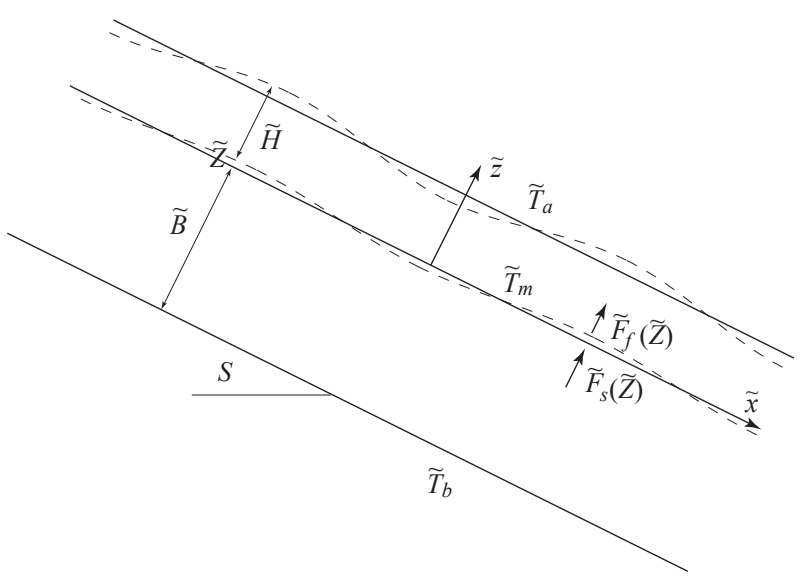

図-3 流れの概念図

凝固点を下回っている場合，疎水性液体が含む水は氷 の上で疑固し，水の表面高さを増加させる．一樣勾配 $S$ の斜面から測った氷の表面高さを $\tilde{Z}$ とする .すなわ ち図-3のような状況を考える.ここで $\tilde{F}_{s}(Z)$ 及び $\tilde{T}_{f}(Z)$ は光れ光れ水表面及び流体底面の熱フラックスを表す 。

\section{(2) 流れの方程式}

サイクリックステップは水平方向の長さスケールが 鉛直方向の長さスケールに比較して卓越した現象 ${ }^{5)}$ で ある. また水の形状変化の時間スケールは流れや温度 の時間変化のスケールと比較して十分に大きいことか ら流れや温度变化の時間微分項を無視し, 水の形状の 時間微分項のみ考慮する準定常の仮定を用いる. 兴のと き流机は次の浅水流方程式で記述できる .

$$
\frac{\partial \tilde{U} \tilde{H}}{\partial \tilde{x}}=0, \quad \tilde{U} \frac{\partial \tilde{U}}{\partial \tilde{x}}=-g \frac{\partial \tilde{H}}{\partial \tilde{x}}-g \frac{\partial \tilde{Z}}{\partial \tilde{x}}+g S-\frac{C_{f} \tilde{U}^{2}}{\tilde{H}}(1 \mathrm{a}, \mathrm{b})
$$


ここで $\tilde{U}$ は水深平均流速, $\tilde{H}$ は水深, $\tilde{Z}$ は水表面の高 さ, $S$ は斜面勾配, $C_{f}$ は底面摩擦係数, $\tilde{t}$ は時間, $\tilde{x}$ は 流下方向座標である.

\section{(3) 熱輸送の定式化}

準定常の仮定を用いると永の熱伝導方程式は次のよ うになる6).

$$
0=k_{s}\left(\frac{\partial^{2} \tilde{T}}{\partial \tilde{x}^{2}}+\frac{\partial^{2} \tilde{T}}{\partial \tilde{z}^{2}}\right)
$$

ここで $\rho_{s}$ は水の密度, $c_{p}$ は水の比熱容量, $\tilde{T}$ は温度， $\tilde{t}$ は時間， $\tilde{x}$ 及び $\tilde{z}$ は光れ光れ流下方向及び水深方向の 座標， $k_{s}$ は水の熱伝導率である. 水の存在する領域は $\tilde{z}=-\tilde{B}$ から $\tilde{z}=\tilde{Z}$ までであるので, 上式が成立する領 域も弚の領域となる。

一方，永上を流れている流体の熱輸送方程式は準定 常の仮定を用いて次のように書ける.

$$
\rho_{f} c_{f}\left(\tilde{u} \frac{\partial \tilde{T}}{\partial \tilde{x}}+\tilde{w} \frac{\partial \tilde{T}}{\partial \tilde{z}}\right)=k_{f}\left(\frac{\partial^{2} \tilde{T}}{\partial \tilde{x}^{2}}+\frac{\partial^{2} \tilde{T}}{\partial \tilde{z}^{2}}\right)
$$

ここで $\rho_{f}$ は流体の密度, $c_{f}$ は流体の比熱容量, $\tilde{u}$ 及び $\tilde{w}$ は光れ午れ流下方向及び深さ方向の流速成分， $k_{f}$ は 流体の熱伝導率である . 流体が存在し，上式が成立す る領域は $\tilde{z}=\tilde{Z}$ から $\tilde{z}=\tilde{Z}+\tilde{H}$ となる .

これらの熱伝導方程式にも浅水流方程式と同樣の浅 水流近似を施す. 水平方向の長さスケールが鉛直方向 の長さスケールと比較して大きいことより, 水平方向 の変化が緩やかであると仮定し, 次の近似を行う .

$$
\frac{\partial^{2}}{\partial \tilde{x}^{2}}<<\frac{\partial^{2}}{\partial \tilde{z}^{2}}
$$

さらに層厚方向に積分すると式 (2) 及び (3) は次のよう に表わされる .

$$
\begin{array}{r}
0=\left.k_{s} \frac{\partial \tilde{T}}{\partial \tilde{z}}\right|_{\tilde{z}=\tilde{Z}}-\left.k_{s} \frac{\partial \tilde{T}}{\partial \tilde{z}}\right|_{\tilde{z}=-\tilde{B}}=-\tilde{F}_{s}(\tilde{Z})+\tilde{F}_{s}(-\tilde{B}) \\
\begin{array}{r}
\rho_{f} c_{f} \frac{\partial \tilde{U} \bar{T}_{f} \tilde{H}}{\partial \tilde{x}}=\left.k_{f} \frac{\partial \tilde{T}}{\partial \tilde{z}}\right|_{\tilde{z}=\tilde{Z}+\tilde{H}}-\left.k_{f} \frac{\partial \tilde{T}}{\partial \tilde{z}}\right|_{\tilde{z}=\tilde{Z}} \\
=-\tilde{F}_{f}(\tilde{Z}+\tilde{H})+\tilde{F}_{f}(\tilde{Z})
\end{array}
\end{array}
$$

ここで $\bar{T}_{s}$ 及び $\bar{T}_{f}$ は流体の層厚平均温度である . 上式 中の $\tilde{F}_{s}(\tilde{Z})$ 及び $\tilde{F}_{s}(-\tilde{B}), \tilde{F}_{f}(\tilde{Z}+\tilde{H})$ 及び $\tilde{F}_{f}(\tilde{Z})$ は光れ 光れ水の表面及び底面における熱フラックス，流体の 表面及び底面における熱フラックスである . 式(6)を連 続式を用いて変形し流体層厚で割ると次式を得る .

$$
\rho_{f} c_{f} \tilde{U} \frac{\partial \bar{T}_{f}}{\partial \tilde{x}}=-\frac{\tilde{F}_{f}(\tilde{Z}+\tilde{H})}{\tilde{H}}+\frac{\tilde{F}_{f}(\tilde{Z})}{\tilde{H}}
$$

ここで熱フラックス $\tilde{F}_{s}$ 及び $\tilde{F}_{f}$ を見積もる方法を考 える、今，流れは定常等流状態であると仮定すると，浅 水流近似を施した式 (2) 及び (3) は次のようになる.

$$
0=k_{s} \frac{\mathrm{d}^{2} \tilde{T}}{\mathrm{~d} \tilde{z}^{2}} \quad(-\tilde{B} \leq \tilde{z}<\tilde{Z})
$$

$$
0=k_{f} \frac{\mathrm{d}^{2} \tilde{T}}{\mathrm{~d} \tilde{z}^{2}} \quad(\tilde{Z}<\tilde{z} \leq \tilde{Z}+\tilde{H})
$$

上式の一般解はいずれも次のように表わされる .

$$
\tilde{T}=a \tilde{z}+b
$$

水の底面では $\tilde{T}_{b}$ となっており, 水の表面 (流体の底面) では温度は氷点 $\tilde{T}_{m}$, 流体の表面では外気温 $\tilde{T}_{a}$ に一致 していると考える.すると次の条件が成り立つ．

$$
\left.\tilde{T}\right|_{\tilde{z}=-\tilde{B}}=\tilde{T}_{b},\left.\quad \tilde{T}\right|_{\tilde{z}=\tilde{Z}}=\tilde{T}_{m},\left.\quad \tilde{T}\right|_{\tilde{z}=\tilde{Z}+\tilde{H}}=\tilde{T}_{a}
$$

これらの境界条件を用いると解は次のように得られる .

$$
\begin{gathered}
\tilde{T}=\frac{\tilde{T}_{m}-\tilde{T}_{b}}{\tilde{Z}+\tilde{B}} \tilde{z}+\frac{\tilde{T}_{m} \tilde{B}+\tilde{T}_{b} \tilde{Z}}{\tilde{Z}+\tilde{B}} \\
\tilde{T}=\frac{\tilde{T}_{a}-\tilde{T}_{m}}{\tilde{H}}(\tilde{z}-\tilde{Z})+\tilde{T}_{m}
\end{gathered}
$$

流れや温度が流下方向に緩やかに変化し, 時間的にも急 激に変化しないとき, 流れや温度の水深方向の構造は等 流状態から大きく外れないことが期待できる．従って， ここでも温度の深さ方向分布は式(13) で表されるとし， 式中の $\tilde{H}$ 及び $\tilde{Z}$ のみが場所によって変化すると仮定す る. すると水の上面 $(\tilde{z}=\tilde{Z})$ 及び流体の下面 $(\tilde{z}=\tilde{Z})$ に おける熱フラックスは弚れ光れ次のように表される .

$$
\begin{aligned}
& \tilde{F}_{s}(\tilde{Z})=-\left.k_{s} \frac{\partial \tilde{T}}{\partial \tilde{z}}\right|_{\tilde{z}=\tilde{Z}}=-k_{s} \frac{\tilde{T}_{m}-\tilde{T}_{b}}{\tilde{Z}+\tilde{B}} \\
& \tilde{F}_{f}(\tilde{Z})=-\left.k_{f} \frac{\partial \tilde{T}}{\partial \tilde{z}}\right|_{\tilde{z}=\tilde{Z}}=-k_{f} \frac{\tilde{T}_{a}-\tilde{T}_{m}}{\tilde{H}}
\end{aligned}
$$

温度が直線分布をしているため, 熱フラックスは深さ 方向に一樣である .

(4) 水表面の高さ変化

水表面の高さ変化は次の式で表わされるとする .

$$
-\rho_{s} h_{l h} \frac{\partial \tilde{Z}}{\partial \tilde{t}}=\tilde{F}_{s}(\tilde{Z})-\tilde{F}_{f}(\tilde{Z})
$$

ここで $\rho_{s}$ は水の密度, $h_{l h}$ は潜熱である.上式は水表面 に下から入ってくる熱フラックス $\tilde{F}_{s}(\tilde{Z})$ と上から出て 行く熱フラックス $\tilde{F}_{f}(\tilde{Z})$ の差によって水の高さが変動 することを意味している .

上式に式 (14) 及び(15) を代入して次式を得る .

$$
\rho_{s} h_{l h} \frac{\partial \tilde{Z}}{\partial \tilde{t}}=k_{s} \frac{\tilde{T}_{m}-\tilde{T}_{b}}{\tilde{Z}+\tilde{B}}-k_{f} \frac{\tilde{T}_{a}-\tilde{T}_{m}}{\tilde{H}}
$$

ここで右辺第一項は水の下方からの熱フラックスを, 右 辺第二項は流体表面からの熱フラックスを表している .

(5) 無次元化

次のような無次元化を導入する.

$$
\tilde{x}=\frac{\tilde{H}_{n}}{C_{f}} x, \quad \tilde{U}=\tilde{U}_{c} U, \quad \tilde{H}=\tilde{H}_{c} H, \quad \tilde{T}=\left(\tilde{T}_{m}-\tilde{T}_{b}\right) T
$$

ここで $\tilde{U}_{c}$ 及び $\tilde{H}_{c}$ は光れ光れフルード数が 1 となる限 界流速および限界水深である . 


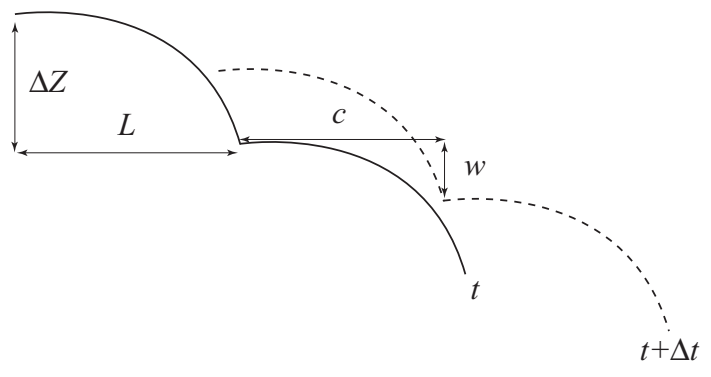

図-4 形状を維持しながら一定速度 $c$ で水平方向に $w$ で鉛直 方向に移動するサイクリックステップ形状 .

無次元化された方程式系は次のようになる .

$$
\begin{gathered}
\frac{\partial U H}{\partial x}=0, \quad U \frac{\partial U}{\partial x}+\frac{\partial H}{\partial x}+\frac{\partial Z}{\partial x}-\sigma+\frac{U^{2}}{H}=0 \\
\frac{\partial Z}{\partial t}=\frac{1}{Z+B}+\frac{\kappa}{H}
\end{gathered}
$$

ここで $\sigma=S / C_{f}$ であり, $\kappa$ は

$$
\kappa=\frac{\tilde{k}_{f}\left(\tilde{T}_{m}-\tilde{T}_{a}\right)}{\tilde{k}_{s}\left(\tilde{T}_{m}-\tilde{T}_{b}\right)}
$$

である . ステップか下流進行したケースをモデルにし ているため, $\tilde{T}_{a}<\tilde{T}_{m}$ であることを意識して上式のよう に置いた . 従って $\tilde{T}_{a}>\tilde{T}_{m}$ の場合は $\kappa$ は負の值を取る . また式 (19c)に，式 (19a) を積分して得られる $U H=1$ の関係を用い，さらに解析を容易にするため，水の層 厚 $\tilde{B}$ は $\tilde{H}_{c} / C_{f}$ より十分小さいが, $\tilde{Z}$ に比べると十分大 きいと仮定することにより $Z$ を無視し， $1 / B$ を $\beta$ で表 すと式 (19c) は次のようになる .

$$
\frac{\partial Z}{\partial t}=\kappa U+\beta
$$

(6) 有限振幅を有するサイクリックステップ形状

a) 座標変換

これまでに導いた方程式系は形状を維持しながら流 下方向へ移動する有限振幅を持ったサイクリックステッ プ解を有する．ここでは光のようなステップの形状を 導く. 次のような座標変換を行う. 水表面の高さ $Z$ を 一定勾配 $\sigma$ の斜面からの高さではなく, 水平面からの 高さ $Z^{*}$ で表す．また斜面方向の座標 $x$ に代えて水平方 向の座標 $x^{*}$ を用いる . 斜面勾配が十分小さいとき次の 関係が成り立つ。

$$
Z=\sigma x+Z^{*}, \quad x=x^{*}
$$

ステップ形状は水平方向 $(x$ の正の方向 ) に $c$, 鉛直下 方に $w$ の速度で移動しているとする . 兴のとき $x^{*}$ の正 の方向に $c$ で移動しながら,$z$ の負の方向に $w$ で移動 する座標 (図-4) を導入すると便利である . 次のような 座標変換を導入する.

$$
\hat{x}=x^{*}-c t, \quad \hat{t}=t, \quad \hat{Z}=Z^{*}+w t
$$

これらの座標変換を用いて式 (21) を書き直すと次のよ うになる。

$$
\frac{\partial \hat{Z}}{\partial \hat{t}}-c \frac{\partial \hat{Z}}{\partial \hat{x}}=\kappa U+\beta-w
$$

b) 正則条件と解の存在条件

移動座標系で見たとき形状を変化させないとすると， 上式の時間微分項はゼロとなって次式が得られる .

$$
-c \frac{\mathrm{d} \hat{Z}}{\mathrm{~d} \hat{x}}=\kappa U+\beta-w
$$

式 (19b)に $U H=1$ の関係を用いて $H$ を消去し, 式 (25) を代入すると次式が得られる .

$$
\frac{\mathrm{d} U}{\mathrm{~d} \hat{x}}=\frac{c^{-1}(\kappa U+\beta-w)-U^{3}}{U-U^{-2}}
$$

フルード数が 1 となる限界点では流速 $U$ は 1 となる 従って上式右辺の分母はゼロとなる . 兴のため正則条 件から次の条件が成り立たなければならない .

$$
c=\kappa+\beta-w
$$

これを式 (26) に代入し約分すると次式が得られる .

$$
\frac{\mathrm{d} U}{\mathrm{~d} \hat{x}}=-\frac{U^{2}\left(U^{2}+U+\frac{\beta-w}{\kappa+\beta-w}\right)}{U^{2}+U+1}
$$

フルード限界点を $\hat{x}$ の原点と取ると $[d U / d \hat{x}]_{z=0}$ は次の 値を取る。

$$
\left.\frac{\mathrm{d} U}{\mathrm{~d} \hat{x}}\right|_{\hat{x}=0}=-\frac{2 \kappa+3 \beta-3 w}{3 \kappa+3 \beta-3 w}
$$

この值が正となるためには分子と分母のどちらかが正 でどちらかが負でなければならない． $\kappa$ が正である場 合, 分母が大きいことは明らかである . 従って分母が 正で分子が負でなければならない．このことから $w$ は 次の範囲に無ければならないことが判る．

$$
\frac{2}{3} \kappa+\beta<w<\kappa+\beta
$$

c) 跳水条件

ステップ上流端及び下流端では跳水が生じている．跳 水前後で成り立つ運動量保存則を無次元化し解くと次 のような関係が得られる .

$$
U_{d}=\frac{1 \pm \sqrt{1+8 U_{u}^{3}}}{4 U_{u}^{2}}
$$

添え字 $u$ はステップ上流端, $d$ はステップ下流端の変数 を意味する .ここで負号では $U_{d}$ が負となるため適さな い. また $U_{u}$ と $U_{d}$ は対称であるから結局次の関係が成 り立つ.

$$
U_{d}=\frac{1+\sqrt{1+8 U_{u}^{3}}}{4 U_{u}^{2}}, \quad U_{u}=\frac{1+\sqrt{1+8 U_{d}^{3}}}{4 U_{d}^{2}}
$$

d) 下流側流速の最大值

式(30)によると式(28)の分母は正であり，また， $\beta-w$ は負である . 今 $\kappa$ は正の值であることに注意する .よっ て式 (28) の分子はゼロとなり得る . 兴のとき $\mathrm{d} U / \mathrm{d} \hat{x}$ は 
ゼロとなり，等流状態となる . 兴のときの流速 $U_{n}$ は次 のようになる .

$$
U_{n}=\frac{-1+\sqrt{1+\frac{4(w-\beta)}{\kappa+\beta-w}}}{2}
$$

上式は $w$ が最小値 $2 / 3 \kappa+\beta$ のとき $U=1$ となり，限界 流速となる . また $w$ が増加するにつれて単調増加し, 最 大值 $\kappa+\beta$ に近づくに連れて無限大となる . 従って上式 で表される $U$ は必ず 1 より大きい . すなわち等流状態 か現れるのは必ず下流側の射流状態の領域である．し かも下流側流速はこの值以上にはなれない .

\section{e) 解法}

一つのステップ上の流速 $U$ の分布は次のようにして 求められる.式(28)より次式が得られる.

$$
-\int_{U_{d}}^{U} \frac{U^{2}+U+1}{U^{2}\left(U^{2}+U+\frac{\beta-w}{\kappa+\beta-w}\right)} \mathrm{d} U=\hat{x}
$$

このとき $w$ は式 (30) を満たすように与える . また $U_{d}$ は $U_{n}$ より大きくなければならない . ステップの波長 $L$ は次式によって求められる.

$$
L=-\int_{U_{d}}^{U_{u}} \frac{U^{2}+U+1}{U^{2}\left(U^{2}+U+\frac{\beta-w}{\kappa+\beta-w}\right)} \mathrm{d} U
$$

この式中の $U_{u}$ は式 (32) を用いて求める .

式 (34) から求められた $U$ を式 (25) に代入して積分 すれば $Z$ が求められる.あるいは式 (27) 及び(28)を式 (26) に代入して次式が求められる .

$$
\frac{\mathrm{d} \hat{Z}}{\mathrm{~d} U}=\frac{(\kappa U+\beta-w)\left(U^{2}+U+1\right)}{(\kappa+\beta-w) U^{2}\left(U^{2}+U+\frac{\beta-w}{\kappa+\beta-w}\right)}
$$

これを積分して次式が得られる .

$$
\hat{Z}=-\int_{U_{d}}^{U} \frac{(\kappa U+\beta-w)\left(U^{2}+U+1\right)}{(\kappa+\beta-w) U^{2}\left(U^{2}+U+\frac{\beta-w}{\kappa+\beta-w}\right)} \mathrm{d} U
$$

また一つのステップの高さ $\Delta \hat{Z}$ は次のように求められる .

$$
\Delta \hat{Z}=-\int_{U_{d}}^{U_{u}} \frac{(\kappa U+\beta-w)\left(U^{2}+U+1\right)}{(\kappa+\beta-w) U^{2}\left(U^{2}+U+\frac{\beta-w}{\kappa+\beta-w}\right)} \mathrm{d} U
$$

式 (35) と (38) から斜面勾配 $\sigma$ が次のように得られる .

$$
\sigma=\frac{\Delta \hat{Z}}{L}
$$

本理論では $\sigma$ を与えるのではなく,$w$ と $U_{d}$ を与えて $\sigma$ を逆算している. 実際は斜面勾配 $\sigma$ が与えられるとス テップ形状は自律的に形成されるはずであるが , この 理論では $w$ 及び $U_{d}$ の二つの変数を与えなければなら ない . $U_{d}$ は 1 より大きく $U_{n}$ より小さい範囲にあれば どのような值を取っても構わない .
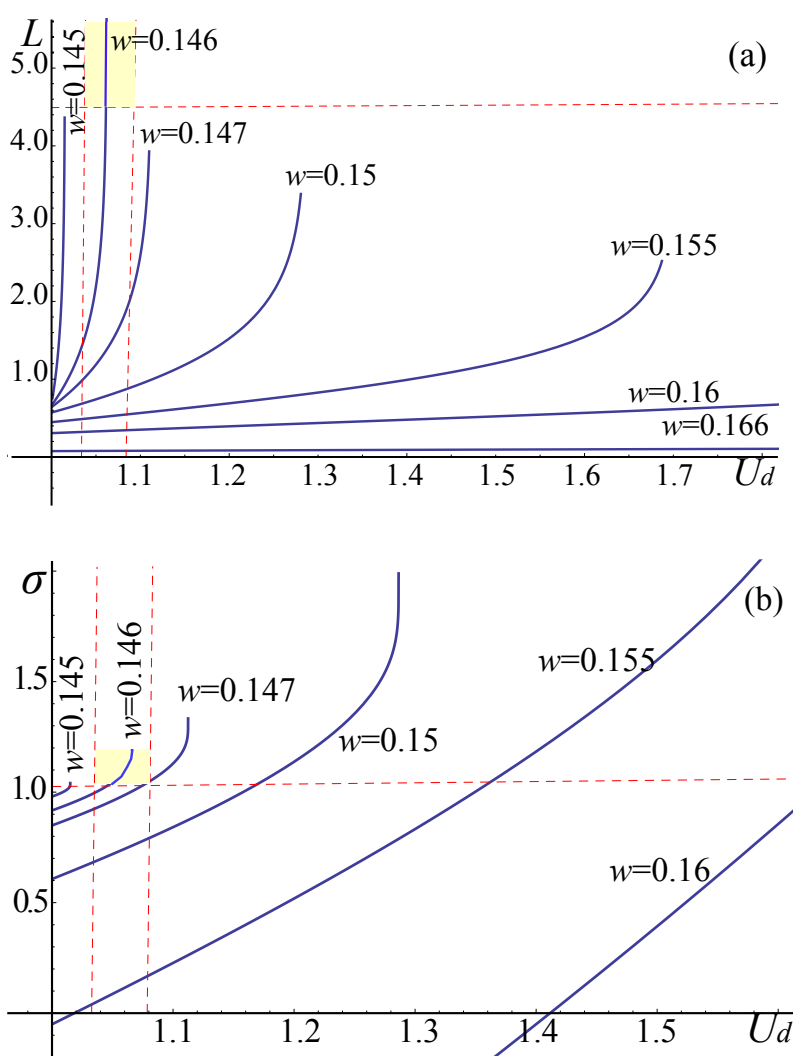

図-5 (a) $U_{d}$ と $w$ による波長 $L$ の変化 . (b) $U_{d}$ と $w$ による勾 配 $\sigma$ の変化.

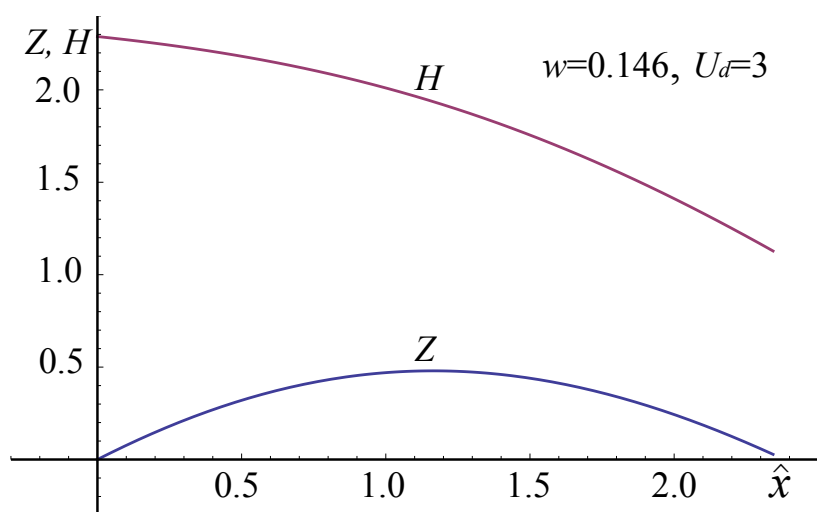

図-6 ステップの形状 $. w=0.146, U_{d}=3$.

\section{4. 結果と考察}

\section{（1）解の存在領域とステップ形状}

$\beta$ 及び $\kappa$ は，既知のパラメータである初期状態におけ る水の厚さ $B$ 及び水，流体光れ光れの熱伝導率 $\tilde{k}_{f}, \tilde{k}_{s}$ によって決定される . また式 (30)によってステップの 移動速度の鉛直成分 $w$ の範囲が 0.145 から 0.166 と決 定される .さらに $w$ と下流端での流速 $U_{d}$ を任意に与 えれば式 (35) から波長 $L$ を決定できる . w を 0.145 か ら 0.166 まで変化させたときの $L$ の $U_{d}$ による変化を 図-5(a) に示す. $U_{d}$ は 1 から等流流速 $U_{n}$ まで取り得る が, $U_{n}$ 付近で無限大になることが判る。これは下流側 
に等流状態が実現すると，どこまでもこの等流状態が 続く状態が理論上は可能であり波長が無限大になり得 ることを示す．また図-5(b) は同樣に $w$ と $U_{d}$ による勾 配 $\sigma$ の変化を示したものである. $U_{d}=U_{n}$ 付近で $L$ は 無限大に発散したのに対して， $\sigma$ はある値に収束する． 図-6 に $w=0.146$ 及び $U_{d}=3$ としたときの $U_{u}$ から $U_{d}$ までの，すなわち一波長上の水の高さ $Z$ と水面 $H+Z$ の変化を示す. 図から明らかなように, 水の高さの変化 がステップ形状を描き，光の上を流れる流体はステッ プ上流部では水深が大きく，下流に進むに従って水深 が小さくなっていく樣子が再現された .

\section{(2) ステップの進行方向}

式 (21) から判るように, 底面高さ $Z$ は水深 $H$ が小さ く流速 $U$ が大きいところほど増加する，すなわち堆積 が生じる.これまでのサイクリックステップでは purely erosional の場合も transportational の場合も流速が大き く底面せん断力が大きいところて侵食が発生した . 従っ てステップ下流部の急勾配部 (射流部) では侵食が活 発に起こり, 逆にステップ上流部の緩勾配部 (常流部) では堆積が生じるため, ステップは全体として上流に 伝播していく. 兴れに対して, 周囲気体の温度 (室温) が融点より低い場合における水上のステップでは, ス テップ下流部の急勾配部 (射流部) では水深が小さい ために低い室温の影響を受けやすく，光の結果オイル に混ざった水分が疑固し堆積が発生するのである.

以上から粘性土や岩盤, 砂面上でステップが発達す る場合, 流速の大きいところでは必ず侵食が起こるた め, ステップは全て上流に伝播するのに対して, 水上 のステップでは外気温が融点より低い場合, 流速の大 きいところで堆積が生じるという正反対の現象が生じ ることが明らかとなった．また，このことから即座に 外気温が融点より高い場合, 上流に伝播することが予 想され，これについては既に著者らの行った別の実験 によって確かめられている7).

\section{(3) 実験值の適用}

ここで実験値を本理論に適用することにより，理論 の整合性を評価する. 実験值には表-1 中の值を平均し 用いる . 実験值を無次元化し，下流端流速 $U_{d}$ と波長 $L$ の值を図-5(a) に適用することにより $w$ の值の範囲か限 定される .ここで無次元化された $U_{d}$ は 0.4 から 0.95 で あり, 無次元化された $L$ の值の範囲は 4.5 から 10.5 で ある . この場合図-5(a)からわかるようにwの值はおよ 弚 0.146 である. 同樣に $U_{d}$ と勾配 $\sigma$ の值を図-5(b) に 適用すると $w$ の値の範囲が限定される . 無次元化され た $\sigma$ の值は 1.0 から 3.0 であり，この場合も図-5(b) か らわかるように $w$ の值はおよ光 0.146 となる . 図-5(a) 及び (b) 中の鉛直方向の点線は実験から得られた $U_{d}$ の 範囲を示している。

$U_{d}$ と $L$ の值を理論に適用することによって求められ た $w$ の值と, $U_{d}$ と $\sigma$ の值を理論に適用することによっ
て求められた $w$ の值が一致している .すなわちこの結 果は本理論と実現象の整合性を示している .

\section{5. 結論}

本研究によって得られた主たる結論は次の通りである．

・水上のステップの形成過程を浅水流近似を用いた 流れの方程式と熱輸送の方程式を用いて定式化し た . 乥れらの方程式を解くことで，下流に進行す る水上のステップ解が存在することが示された .

- 実験で得られた $U_{d}$ と $L$ から $w$ を推定するととも に， $\sigma$ を求めたところ，実験結果と良好な一致を 示した .これは理論と実現象の整合性を示すもの である .

・永上に形成されるステップ地形の場合, 兴の進行 方向は外気, 流体, 水の温度分布によって決定さ れ, 外気温が融点より低い場合, 水上には下流に 進行するステップ地形が形成され得る. 外気温が 融点より高い場合, 水上には上流に進行するステッ プ地形が形成され得る .

・ 火星極冠において, ステップ地形は水上を流れる 密度流によって形成されるものであり，流速が大き く水深が小さな部分で水が水蒸気へと昇華し, 一 方流速が小さく水深が大きな部分では流体中の水 蒸気が水へと凝固し水上に沈殿することによりス テップ地形が上流へ進行していると考えられる．

\section{参考文献}

1) Kostic, S. and Parker, G.: A phenomenon of supercritical shallow flow from the high mountains to the bottom of the ocean, Journal of Hydro-environment Research, Vol.3, pp.167-172, 2010.

2) Parker, G. and Izumi, N.: Purely erosional cyclic and solitary steps created by flow over a cohesive bed, Journal of Fluid Mechanins, Vol.419, pp.203-238, 2000.

3) Smith, I. B. and Holt, J. W.: Onset and migration of spiral troughs on Mars revealed by orbital radar, Nature, Vol.465, pp.450-453, 2010.

4) Lunar and Planetary Lab. University of Arisona: The Polar Deposits of Mars, Annual review of Earth and Planetary science, 2009.

5) Sun, T. and Parker, G.: Transportational cyclic steps created by flow over an erodible bed. Part 2. Theory and numerical simulation, Journal of Hydraulic Research, Vol.43, pp.502514, 2005.

6) Faghri, A. and Zhang, Y.: Transport Phenomena in Multiphase Systems (Chapter6:Menting and Solidification, Chaper7: Sublimation and vapor deposition), Elsevier, 2006.

7) 横川美和, 泉 典洋, 内藤健介, 山田朋人, Ralf GREVE: 水上 のステップ地形に関する実験的研究, 水工学論文集, 第 57 巻, 2013 (印刷中) .

(2012.9.30 受付) 